\title{
X-CULTURE: AN INTERNATIONAL PROJECT IN THE LIGHT OF EXPERIENCE GAINED OVER THE YEARS (2010-2016)
}

\author{
József Poór \\ J. Selye University, Komárno, Slovakia \\ Szent István University, Gödöll, Hungary \\ Erika Varga \\ Szent István University, Gödöll, Hungary \\ Renata Machova \\ J. Selye University, Komárno, Slovakia \\ Vas Taras \\ University of North Carolina, Greensboro, USA
}

\begin{abstract}
The X-Culture project is an innovative modern form of experiential learning predominantly in International Management and International Business. Although experiential learning has some advantages, namely, developing cross-cultural competencies, cultural intelligence, intercultural communication and management skills, differences in personality or conditions also arise as a downside. X-Culture has been evolving throughout the years since 2010 when the original objective was to supplement the theoretical material and in-class teaching. Nowadays more than 4000 master, bachelor and MBA students, mostly of management and economics from more than 37 countries, take part in the project every semester. X-Culture is aimed at students of International Business college courses and training programs with the task of writing a business report or consulting propositions by offering business solutions for a hypothetical client. This paper outlines the theoretical background of the Xculture project. It describes the evolution and practical and theoretical experience of this project since 2010.
\end{abstract}

Keywords: X-culture, Experiential learning, Theoretical and practical experience, International management.

DOI: http://dx.doi.org/10.15549/jeecar.v3i2.139

INTRODUCTION

Our paper discusses X-Culture, a large-scale international business student collaboration project and business plan competition. Every semester over 4,000 students from 100 universities in 40 countries participate in it. Most of them have been enrolled to International 
Business courses at different universities. The students, usually in global virtual teams of seven, work with each student on the team coming from a different country. The project serves as an excellent opportunity for collaboration across courses and universities.

The initial idea for X-Culture was rooted in an attempt to find a colleague abroad who would like to team up his or her students with student for a different country to develop a joint team project. Collaboration was announced via the Academy of International Business mailing list. Surprisingly, within a short time, a number of academic collaborators from around the world expressed their interest in joining the project. And so XCulture was born.

The first time (fall of 2010), lecturers from seven countries took part with their students. A total of about 450 students participated. Since then the project has been growing each semester, reaching almost 3,000 students, from 100 universities in over 40 countries as of spring 2014. Table 1 provides more details on the participation numbers for the project.

Table 1. X-Culture Participations Dynamics

\begin{tabular}{rrrrr}
\hline Season & Students & Teams & Universities & Countries \\
\hline $2010-2$ & 463 & 125 & 7 & 7 \\
$2011-1$ & 682 & 157 & 15 & 15 \\
$2011-2$ & 1,150 & 145 & 26 & 22 \\
$2012-1$ & 1,889 & 307 & 42 & 38 \\
$2012-2$ & 2,105 & 280 & 54 & 39 \\
$2013-1$ & 2,447 & 435 & 75 & 41 \\
$2013-2$ & 2,567 & 379 & 84 & 42 \\
$2014-1$ & 2,642 & 399 & 99 & 43 \\
$2014-2$ & 2,910 & 452 & 101 & 43 \\
$2015-1$ & 3,050 & 455 & 107 & 43 \\
$2015-2$ & 3,718 & 667 & 112 & 42 \\
$2016-1$ & 3,738 & 750 & 110 & 40 \\
\hline Total & 27,361 & 4,623 & 301 & 61 \\
\hline
\end{tabular}

Source: Project's administrative records

\section{THEORETICAL BACKGROUND}

$\mathrm{X}$-Culture is part of experiential learning theory that dates back to the beginning of the $20^{\text {th }}$ century, based on Jacob Levy Moreno Kurt Lewin's social psychology experiments used in management education and training (Highhouse, 2002).

As Kolb (1984) states "Learning involves transactions between the person and the environment" (p. 35). More specifically, experiential learning is "the process whereby knowledge is created through the transformation of experience. Knowledge results from the combination of grasping and transforming experience" (Kolb, 1984: 41).

More recent theories of experiential learning can be traced back to earlier theories of human development and psychology of learning (John Dewey, Paulo Freire, William James, Kurt Lewin, Jean Piaget, and Carl Rogers, amongst others).

According to the Experiential learning theory (ETL) the learning process consists of four dynamic modes involving action/reflection and experience/abstraction (Kolb \& Kolb, 2009): concrete experience $(\mathrm{CE})$, reflective observation (RO), abstract conceptualization (AC), and active experimentation (AE). The ETL model is based on three stages of human development: acquisition, specialization, and integration (Kolb, 1984). ELT suggests that the learning cycle includes experiencing, reflecting, thinking and acting, and that concrete experiences are the foundations for observations and reflections (Kolb \& Kolb, 2009).

Several studies have emphasized the positive effect of the practical component in economics (Herz \& Merz, 1998), marketing (Gremler, Hoffman, Keaveney, \& Wright, 2000), business communication (Saunders, 1997), entrepreneurship (Cooper, Bottomley, \& Gordon, 2004) and other fields (for review studies see Cantor, 1997; Gosen \& Washbush, 2004; Kolb, Boyatzis, \& Mainemelis, 2001).

Few empirical studies were written on the relationship between learning styles and cultural background (Joy \& Kolb, 2009). Kolb (1984) discusses that experience plays a central role in both human adaptation and the learning process, rather than in acquisition, manipulation and abstraction (as other learning theories). 
Experiential learning approaches can most challengingly be used in International Business and Management training and education as simulating multi-cultural global environment in the classroom is often a daunting or even an impossible task. There have also been studies evaluating experiential learning in the field of International Business and Management education (Taras et al., 2013).and using virtual teams as experiential learning vehicles (Gonzalez-Perez et al., 2014).

Experiential learning tools have increased in the recent years (Hawtrey, 2007). Several studies show that experiential learning is has a positive effect on learning in general business education (Alon, 2003; Krbec and Currie, 2010 among others).

\section{MATERIAL AND METHODS}

$\mathrm{X}$-Culture is a great example for experiential learning in International Business. X-Culture is a good way to develop cross-cultural competencies. Moreover, cross-cultural interaction also contributes to developing cultural intelligence (Early and Peterson, 2004).

Although X-Culture is unique in some respects, it is similar to other exercises such as Global Marketing Management System Online - GMMSO (Janavaras, 2012) and GEO (Thavikulwat, 2007a, 2007b). GMMSO has a similar task to the one use in X-Culture while GEO primarily focuses on international trade. Other projects such as Global Business Game or Global View have also sameclass teams.

The basic difference between X-Culture and other experiential learning projects is that while the former one uses publicly available resources (e.g. Skype, Dropbox, Google Drive, Google Docs, Facebook, Skype, Viber, and WhatsApp among others) so that the students can continue using them in other projects, the latter one relies on specially designed platforms or simulators.

$\mathrm{X}$-Culture is an excellent opportunity for students to experience international collaboration first-hand. The students are divided into Global Virtual Teams, usually about 7 students per team. Sometimes the student teams are smaller (only 4 or 5 students) or larger (up to 11 students). Also, depending on the number of the participants, some teams would have two students from the same country (usually United States. that tends to be overrepresented).

Although X-Culture takes up an entire semester, the time for the teams to work together is limited to a little over two months. As the semester length varies considerably across different countries, the active collaboration period is shorter than a typical semester.

The basic task for X-culture students was to write a business report for a hypothetical client following the structure of an International Business textbook and covering issues related to differences in economic, political, and cultural environment, international market entry modes, international strategy, marketing, and so on. Later on, the X-Culture task has been evolving towards more creative and more universal components.

In most cases, the students would choose large multi-national corporations, such as Walt Disney Company, BMW or Apple. Typically, the companies were not aware of the work the students were doing but in 2013 companies started contacting XCulture and inquiring if they could present their real-life challenges that the student could try to tackle.

Mostly, medium-sized and smaller companies were particularly interested but a number of large multinational corporations also expressed interest in collaborating with X-Culture. For example, Daimler AG requested ideas for a new truck for developing countries.

In the first year of the program students were asked to devise a concept connected to the 6 million-dollar investment plan for Capstone, a medium-sized American company in international teams of four. Later on, the subject of case studies shifted to working out business solutions for large corporations or other companies of their choice including

- the German trade concern, ALDI

- BP international oil concern,

- Google international IT company,

- HSBC, the world's second largest commercial bank,

- McDonald's, the world's largest fast food chain,

- Toyota, one of the biggest car manufacturers,

- VF from the textile industry and 
- Or the well-known Walt Disney Entertainment.

In addition to virtual collaboration, X-Culture added personal meetings of the best students at semi-annual X-Culture symposium. The ultimate goal is to give students and opportunity to experience the challenges and learn the best practices of international collaboration while gaining business knowledge and skills.

X-culture database contains more than 1,200 variables. Over 2,500 cases (400 teams) are added to the database every semester. The student and instructor surveys include over 500 questions asked over the course of the project. Overall, the XCulture database contains over 2,000 variables at the individual level of measurement, and about 500 variables at the team level. Experiments have also been started with different learning conditions, team composition, assignments, and evaluation systems to see which teaching approach gives the best learning outcome and student satisfaction.

The main research questions include finding more information on workgroup dynamics and improving performance in the global workplace. Moreover, the effects and effectiveness of experiential learning are also analyzed not only in International Business but also in Management, Psychology, Marketing, Economics, Sociology, and other disciplines.

\section{RESULTS}

The principle objective of the $\mathrm{X}$-Culture project is to provide students with an opportunity to experience the challenges of cross-cultural collaboration and thereby improve learning in International Business Courses. A recent study published in the Academy of Management Learning and Education (Taras et al, 2013) detailed the findings of a multi-study evaluation of effectiveness of X-Culture.

The results show that in addition to raising student satisfaction with their course, X-culture also improves cultural intelligence, reduces stereotypes, induces interest in further crosscultural interactions, and actually improves student performance on tests.

Environment and individual differences, such as personality, geographical location, culture, occupation, age, time availability, educational background, personal history, gender, genetic information, social status, and expectations, may influence different learning abilities. In Table 2, some of the expected challenges (before participating in X-Culture) relate to their observed challenges (after participation).

Table 2. Expected vs. Observed Challenges of International Collaboration

\begin{tabular}{lcc}
\hline Challenge & Expected & Observed \\
\hline Cultural differences & 28.2 & 2.9 \\
Language differences & 21.2 & 7.0 \\
Time zone differences & 20.6 & 15.5 \\
Other communication & 20.5 & 11.1 \\
barriers & 16.2 & 34.8 \\
Coordination &
\end{tabular}

Source: Authors' own research

However, some outcomes were unexpected. Students shared their experience how X-Culture helped them land internships and jobs. It supports the belief many companies really value first-hand international experience. Many students developed close personal connections with their team members and stayed in touch long. Some teams informed us that they considered staring a business around the business proposal they developed for X-Culture.

\section{CHALLENGES AND BEST PRACTICES}

\section{Recruitment}

Participants are recruited by sending calls through the Academy of International Business (AIB) and Academy of Management (AOM) mailing lists. Also, many new participants are recruited by the word-of-mouth. The number of applications has been rapidly growing since the project was first launched. Most of the applications come from North America and Europe where the Academy of International Business and Academy of Management have most of their membership. Africa, Asia, and Latin America still remain underrepresented, although the number of applications from these regions is steadily growing.

\section{Selection}

$\mathrm{X}$-Culture receives hundreds of applications each 
semester. At the beginning, all applications were automatically accepted. Nowadays, after selection only a few applications are approved as quality is given more attention. As the students work in large teams, even one underprepared or undercommitted student can spoil the experience, so selection is a very important issue.

All students are subject to a Readiness Test. Prior to the test, the students are expected to review materials on X-Culture including instructions and a student training module. Then the students take an online test on the project rules and procedures, online collaboration tools, as well as assess their interest and commitment. Additionally, the test also provides some information on the student's ability to communicate in English, if only with written test. The test also ensures that each student has access to the internet and his or her email address works.

\section{Academic Calendar Difference}

The biggest challenge is that the academic schedule varies across regions of the world. For example, the long summer break tends to be in June-August in the Northern hemisphere and in December-January in the Southern hemisphere. The semester start and end dates vary considerably across locations, some universities are at semester schedule, some use trimesters, and some use quarters.

To tackle the schedule difference problem, XCulture is run in two tracks every semester. The early track starts earlier and the late track starts later, by about six weeks. Although the students in the early track generally do not directly communicate with the students from the late track, they often exchange ideas on the X-Culture Facebook page. Both tracks tend to be quite popular with enough countries represented.

\section{Pre-project training}

The well-preparedness of each student is essential for the success of the X-Culture experience. That is why a standardized mandatory pre-project training module for students was developed to which new features are added. Strategies have been shown to be effective when dealing with these challenges. Additionally, the students can watch a 20-minute long video interview with former X-Culture participants where they share their experiences and advice for future participants. The X-Culture Facebook page also provides records of discussions of challenges.

Before the project starts, each student receives a Welcome Letter with a link to an X-Culture preproject training page. The students are instructed to review all X-Culture materials and take a Readiness Test. This way, all students have an opportunity to receive quality training regardless of how experienced their instructors are with XCulture. Still, individual instructor support is paramount. There is a huge difference in student performance across instructors. Of note, instructors need training too. A similar training module for instructors, named Instructor's Handbook, has also been developed. The document contains a detailed overview of everything an instructor needs to know about X-Culture, including links to external sources, templates, FAQ, and other materials.

\section{Grading}

Since the project is part of the required coursework, student performance grading is an important issue. Instructors are asked to evaluate performance of their students and give them a fair grade, which is a powerful motivator for the students to do well in the project. After the initial enthusiasm, when faced with the demands and requirements of the project, many would simply dropout or do not perform up to the expectations of their team members.

Therefore, to ensure that all students are fully committed to the project, it is now required that:

- The X-Culture project must account for no less than $20 \%$ of the course grade/mark;

- Peer evaluations account for no less than $20 \%$ of the X-Culture project grade/mark;

- Every milestone (there are a total of 10 throughout the project) must be included in the project grade.

The instructors receive weekly updates on their student performance. Most instructors have one final grade for the project, but many have weekly grades. It is very important to underscore that XCulture project is rather designed to help students gain knowledge and skills than evaluate performance by grades. 
Table 3. Grading system design

\section{Performance Indicator}

Individual:

Completion of the pre-project training (completed before the deadline, \% correct answers, check for response non-randomness);

Weekly progress reports, submitted individually by each student (completed fully and before the deadline)

Post-project survey (completed before the deadline, \% questions answered, check for response non-randomness);

Peer evaluations (as evaluated by the other team members in terms of

effort, intellectual contribution, help with writing the report, 25\% coordinating team efforts, other comments).

\section{Team}

Quality of the team report (as rated by the instructors along 7 report quality dimensions)

Source: Authors' own compilation

The pre-project training test and the post-project survey are mandatory components of the project to ensure that students come sufficiently prepared and that all necessary data are collected.

\section{THE CENTRAL EUROPEAN EXPERIENCE OF THE PROJECT}

One of the consequences of globalization is that the various forms of contact with our business partners are becoming independent of place. Changes take place extremely fast and to teach how to adapt to them successfully at school tends to be very difficult. Adaptation to the new dimensions of business life can be eased if the students of economics and management can take part in international cooperation. It is when the students of Selye János University (SJU), Faculty of Economics and Szent István University (SZIU), Faculty of Economics and Social Sciences majoring in Management and Business Administration, BSc have taken part in this program coordinated by Greensboro University in the USA. In addition to the existing Erasmus student exchange program, $\mathrm{X}$-Culture serves as a very modern cooperative form of studying for all the students who would like to improve their English knowledge. Table 4 below illustrates the changes in the number of students participating in the project between 2011 and 2016.

\section{Recommended Value}

Must be completed to enrol $^{*}$

$5 \%$

Must be completed to receive project grade/mark ${ }^{*}$

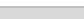

$45 \%$ 
Table $5 \mathrm{X}$-Culture experience of Slovakian and Hungarian students

\begin{tabular}{|c|c|}
\hline No. & Students' opinion \\
\hline 1. & $\begin{array}{l}\text { A correspondent student: It was most interesting to work together with my team } \\
\text { members who came from different parts of the world. At first I did not even know on the } \\
\text { basis of the names, except Brianna, whether it is a boy or a girl :) As far as team work is } \\
\text { concerned, I can say that everyone had an equal share of it, except Cheng Yang, who did not } \\
\text { take part at all. It was not obvious at all that our team was made of totally different cultures. } \\
\text { Everyone kept promises and we helped one another. We also talked about private issues in } \\
\text { addition to work and we are still friends on several social media platforms. We promised to } \\
\text { advise the others should we travel to their country. Despite of the initial fear, primarily due } \\
\text { to language barriers, I can say that I can assess the program only positively and thank you } \\
\text { for the opportunity to have gained such precious experience. }\end{array}$ \\
\hline 2. & $\begin{array}{l}\text { A full time student: During my participation in X-Culture program I gained a lot of } \\
\text { experience. There were many challenges and we had to find the solutions. We also had to } \\
\text { face cultural differences, language barriers and different time zones, as well. We were trying } \\
\text { to find the best solutions to the problems with my team mates. To this end, we were } \\
\text { negotiating regularly, almost on a daily basis. Due to this, not only our English improved } \\
\text { but also our communication skills and our cooperation with people from different cultures. } \\
\text { All in all, I can say that my participation in the program was very advantageous. }\end{array}$ \\
\hline 3. & $\begin{array}{l}\text { A full time student: X-Culture program made it possible for me to participate in an } \\
\text { international program with students from different parts of the world. So the program } \\
\text { significantly contributed to getting to know different cultures, customs and traditions to } \\
\text { extend my knowledge. In addition, I also gained experience in international management as } \\
\text { we had to work out a successful business plan for a company. Of course, there were } \\
\text { hardships but fortunately, they could be managed It was difficult to make appointments a } \\
\text { sin certain cases there were } 10 \text { hours' difference in time. To cooperate more efficiently, we } \\
\text { tried to keep in touch and talk every day. I think X-Culture served as an excellent } \\
\text { opportunity for making friends so I can recommend it for all young students who wish to } \\
\text { gain experience. }\end{array}$ \\
\hline
\end{tabular}

Source: Authors' own compilation

Just like in the previous years, all the students participating in the program agreed that participation in such an international program is very useful. Although problems arose while working together, they could be solved, fortunately. As a result, not only their language skills and communication improved but also their willingness to cooperate from someone from a different cultural background. X-Culture also served as an excellent opportunity to make friends. To sum up, participation in the program resulted in mainly gains and benefits.

\section{CONCLUSION AND RECOMMENDATIONS}

As our students have been participating in the International Student Collaboration Project since 2011, they are asked to share their experience with us, what they think the challenges are and also what knowledge and skills they gained while working with other team members from different parts of the world.

To sum up, the following points were made:

a Most participants considered the program to be very useful.

- The following points were stressed in connection with acquiring tacit knowledge competencies: 
1. The program assisted in developing these competencies most.

2. They made the greatest progress in understanding and communicating with others from different cultures.

3. They also improved their skills in organizing and managing non-hierarchical team work.

4. The students also appreciated working and collaborating with the others from different working cultures. In some cases they had to cover or replace their slower teammates or the dropouts but generally, they could succeed in doing so, as well.

5. Of the labor market competencies projected by the Institute for the future in their study „Future work skills 2020” XCulture improved some, among others, virtual work. (http://www.iftf.org/ uploads/media/SR1382A_UPRI_future_wor $\mathrm{k} \_$skills_sm.pdf)

- As far as explicit knowledge competencies are concerned, the participants highlighted the following ones:

1. Using new social media platforms, mostly e-mails, Facebook and Google Doc.

2. Deadlines were met in most cases and project tasks could be completed.

Within the framework of a program of such nature, it is natural to experience not only positive things but also some hardships such as different cultural background or the significant differences in time due to the time zones.

$\mathrm{X}$-Culture is still very much work in progress. Every semester changes are made and the format of the project is modified together with the task, policies and procedures.

Our immediate plans include experimenting with a few new features of the project.

First, we are considering running X-Culture in languages other than English. There are regular request to have a Spanish language track for Latin America and Spain, and possibly a French track for French-speaking countries.

Second, we are considering adding a nonbusiness track. At this time, pretty much all XCulture participants are business students and, hence, the task is very much business related.
However, international collaboration is equally important in arts, engineering, natural sciences, and humanities. We are exploring opportunities to add a group of students from non-business disciplines with a task that is more suitable for their areas of studies.

Third, we would like to expand our collaboration with real-life businesses. Our initial experience with our corporate partners has been extremely positive. Not only do the companies receive valuable input and ideas from our bright students. Involvement of real business and work on real-life business challenges makes the project more practical and educational for the students. Furthermore, working with a real company, students get a chance to impress their "clients" and possibly get a chance of an internship or a job.

Fourth, we would like to devote more attention to exploring funding opportunities. At some level, volunteer time is not sufficient to run a successful project. Even Wikipedia has a small group of paid staff. In addition to exploring grant options, we are also considering soliciting sponsor funding.

Finally, in our spirit of open collaboration, we are experimenting with opening up our immense database to the public and inviting researchers of all background and interests to download our data and use them in their research. While it is common in the publish-or-parish academic community to closely guard one's own data, we believe open data sharing and collaboration will speed up knowledge creation and ultimately benefit all parties.

\section{REFERENCES}

Alon, I. (2003). Experiential learning in international business via the World Wide Web. Journal of Teaching in International Business, 14(2-3), 79-98.

Cantor, J. A. (1997). Experiential Learning in Higher Education: Linking Classroom and Community. ERIC Digest.

Cooper, S., Bottomley, C., \& Gordon, J. (2004). Stepping out of the classroom and up the ladder of learning: An experiential learning approach to entrepreneurship education. Industry and Higher Education, 18(1), 11-22.

Gonzalez-Perez, M.A.; Cathro, V. Caprar, D.V. \& Taras, V. (2014) Virtual Teams and International Business Teaching and 
Learning: The Case of the Global Enterprise Experience (GEE). Journal of Teaching in International Business. [In Press]

Gosen, J., \& Washbush, J. (2004). A review of scholarship on assessing experiential learning effectiveness. Simulation \& Gaming, 35(2), 270-293.

Gremler, D. D., Hoffman, K. D., Keaveney, S. M., \& Wright, L. K. (2000). Experiential learning exercises in services marketing courses. Journal of Marketing Education, 22(1), 35-44.

Hawtrey, K. (2007). Using experiential learning techniques. The Journal of Economic Education, 38(2), 143-152.

Herz, B., \& Merz, W. (1998). Experiential learning and the effectiveness of economic simulation games. Simulation \& Gaming, 29(2), 238-250.

Highhouse, Scott (2002) A history of the T-group and its early applications in management development. Group Dynamics: Theory, Research and Practice. Vol. 6(4), 277-290.

Janavaras, B. J., \& Gomes, E. (2012). Global Business Research and Strategic Planning Tools. Journal of International Business and Economy, 8(1), 59-70.

Joy, Simy \& Kolb, David A. (2009) Are there cultural differences in learning styles? International Journal of Intercultural Relations. Vol. 33(1), 65-89.

Kolb, D. A. (1984). Experiential learning:

Experience as the source of learning and development (Vol. 1): Prentice-Hall Englewood Cliffs, NJ.

Kolb, Alice Y. \& Kolb, David A. (2009) Experiential learning theory: A dynamic, holistic approach to management learning, education and development. In: Armstrong, S.J. \& Fukami, C.V. (2009) The SAGE Handbook of Management Learning, Education and Development.

Kolb, D. A., Boyatzis, R. E., \& Mainemelis, C. (2001). Experiential learning theory: Previous research and new directions. Perspectives on thinking, learning, and cognitive styles, 1 , 227-247.

Krbec, D., \& Currie, D. M. (2010). Advantages of experiential learning in development of international economics and business study programs. Izlazi u Samo Elektroničkom
Izdanju.

Saunders, P. M. (1997). Experiential learning, cases, and simulations in business communication. Business Communication Quarterly, 60(1), 97-114.

Taras, V., Caprar, D. V., Rottig, D., Sarala, R. M., Zakaria, N., Zhao, F., ... Minor, M. S. (2013). A global classroom? Evaluating the effectiveness of global virtual collaboration as a teaching tool in management education. Academy of Management Learning \& Education, 12(3), 414-435.

Thavikulwat, P. (2007). Demonstration of a Computer-Assisted Global Business Simulation. Developments in Business Simulation and Experiential Learning, 34, 111-112.

Thavikulwat, P., \& Chang, J. (2007). Applying .NET Remoting to a Business Simulation. Developments in Business Simulations and Experiential Learning, 34, 113-118. 


\section{ABOUT THE AUTHORS}

József Poór email: poorjf@t-online.hu

Dr. József Poór, CMC is a Professor of Management of J.Selye University (Slovakia) and Szent István University (Hungary), where he teaches a variety of management courses. He served as a guest professor at five different U.S. universities and taught fourteen short summer semesters. He was senior manager at internationally recognized professional service firms (Mercer, HayGroup, Diebold) and at the International Management Center, Budapest. His scholarly publications have appeared in more than fifteen internationally referred journals. He wrote many books in Hungarian, and seven book-chapters in English and one book in Romanian alone or as a co-author.

Dr. Erika Varga graduated from the Faculty of Arts and Sciences, majoring in History and English. Erika Varga obtained her doctoral degree in 2015 at the PhD School of Management and Business Administration of Szent István University after studying the significance of personal competencies in human resource management and in business-oriented higher education. Her research topics include recruitment, election and the examination of competencies together with multiculturalism and the analysis of intercultural competence. She regularly publishes in international and Hungarian journals, presents at conferences and actively takes part in the work of V4 research groups.

Dr. Renata Machova is a Assistant Professor of Management of J. Selye University (Slovakia), where she teaches a variety of management courses. Her scholarly publications have appeared in more than five internationally referred journals. She wrote several books in Hungarian and in Slovak alone and as coauthor.

Dr. Vas Taras received his $\mathrm{PhD}$ in International Human Resource Management and Organizational Dynamics from the University of Calgary, Canada and his Master's in Political Economy from the University of Texas at Dallas. He teaches International Business at the Bryan School of Business and Economics at the University of North Carolina at Greensboro. He is the X-Culture Project Coordinator. His research revolves around cross-cultural and global virtual teams and experiential approaches to international business education. He is a recipient of numerous research and teaching awards for his work in International Business. 